\title{
VLIVY HELFERTOVÝCH ŽÁKŮ NA POVÁLEČNOU OSTRAVSKOU HUDEBNÍ VĚDU
}

V publikaci o ostravské hudební kultuře vydané v Ostravě před čtyřmi roky se uvádí: „[...] pro pěstování většiny hudebněvědeckých disciplín na Ostravsku nebyly vždy ty nejlepšsi podmínky [... " ", ${ }^{1}$ a to hlavně proto, že zde chybělo vědecké pracoviště takového typu, jako jsou univerzitní či akademické muzikologické ústavy a katedry v Praze, Brně či Olomouci. Po zrušení muzikologického oddělení ve Slezském studijním ústavu v Opavě, které vybudoval v letech 1954-1963 nestor ostravských hudebních historiků Ivo Stolařík (1923-2010), za velké podpory Helfertových žáků, profesorů Jana Racka i Bohumíra Štědroně, zde zbyla jen dvě hudební oddělení v muzeích (ve Slezském muzeu v Opavě a v Ostravském muzeu). Od začátku 60. let se však stále výrazněji na hudebněvědeckém poli uplatňovalo - vedle svého hlavního poslání vychovávat učitele hudby a hudební výchovy - další ostravské pracoviště - katedra hudební výchovy v roce 1959 vzniklého Pedagogického institutu. ${ }^{2}$ Duší této katedry se bezesporu stal její vedoucí Vladimír Gregor (1916-1986). Gregor ${ }^{3}$ spolu s mladším Ivem Stolaříkem skutečně patřili $\mathrm{k}$ zakladatelům hudebněvědeckého oboru na Ostravsku a dosud patř́ $\mathrm{k}$ jeho nejvýznamnějším představitelům. Oba vzešli z brněnské muzikologické školy, na oba v jejich vědeckých začátcích nejvíce působili profesoři

1 Srovnej MAZUREK, Jan - STEINMETZ, Karel et al. Ostravská hudební kultura od konce 19. století do současnosti. 1. vyd. Ostrava: Ostravská univerzita - Pedagogická fakulta, 2010, s. 152.

2 Ostravský Pedagogický institut se o pět let později transformoval na Pedagogickou fakultu v Ostravě, která se v roce 1991 začlenila do nově vzniklé Ostravské univerzity v Ostravě.

3 Vladimír Gregor se narodil 10. 12. 1916 v Olomouci. V rodišti vystudoval učitelský ústav. Po krátké učitelské praxi nastoupil před válkou na brněnskou Masarykovu univerzitu (dále jen MU; obory čeština, němčina a hudební věda), po válce zde pokračoval, ale svá univerzitní studia dokončil v Olomouci na Palackého univerzitě v roce 1949. Studia hudební vědy završil obhájením disertace Olomoucký skladatel Ludvik z Ditrichů a jeho písen̆ Moravo, Moravo (1950) na MU v Brně. Pak působil na Palackého univerzitě na katedře hudební vědy a výchovy do roku 1959, kdy přešel do Ostravy. Zde rozvinul bohatou vědeckou a pedagogickou činnost, zvl. na katedře hudební výchovy Pedagogického institutu (později Pedagogické fakulty). V Ostravě také 5. 2. 1986 zemřel. 
Jan Racek a Bohumír Štědroň. ${ }^{4}$ Zatímco Stolařík zde vědecky pracoval už v první polovině 50. let, Gregor přišel do Ostravy až na podzim roku 1959 na zdejší Pedagogický institut jako vedoucí katedry hudební výchovy. Jeho vědecká aktivita byla tehdy zaměřena zejména na regionální hudební historii Moravy a Slezska 18., 19., ale i 20. století a otázky regionálního hudebního života. Ještě v olomouckém období byla první větší vydanou prací regionalistické orientace Hudební vlastivěda Olomouckého kraje..$^{5}$ když měla tato knížka spíše popularizační poslání, nesla všechny základní znaky pozdějších autorových vědeckých počinů: přinášela velké množství pečlivě utříděných a často nových faktů, které byly posuzovány v širších hudebních, obecně historických i společenských souvislostech, měla podrobný poznámkový aparát, soupis pramenů a studijní literatury, různé druhy rejstř́ků a bohaté obrazové př́lohy.

V tomto směru na Gregora hlavně působil jeho univerzitní učitel Bohumír Štědroň, s nímž také Gregor společně napsal a vydal svou první knížku Leoš Janáček, největši český skladatel z Moravy. ${ }^{6}$ Bohumír Štědroň pak zaměřil celoživotní Gregorovo pracovní úsilí nejen na regionální hudebněhistorickou problematiku (třeba i včetně studií o Janáčkových spolupracovnících z regionu ${ }^{7}$ ), ale též na dějiny české hudební pedagogiky. ${ }^{8} \mathrm{Z}$ olomouckého období připomeňme ještě např́klad dvě Gregorovy knížky Česká dětská piseň umělá a Olomoucká a vídeňská léta skladatele A. Förchtgotta-Tovačovského ${ }^{10}$ či větší, zejména ma-

4 Ti vlastně iniciovali muzikologický a etnografický průzkum českého Slezska a Ostravska. Srv. BOŽENEK, Karel. Př́inos Iva Stolaříka k rozvoji hudební historiografie Slezska a Ostravska. In STEINMETZ, Karel - BOŽENEK, Karel-MAZUREK, J. Ivo Stolařík : Osobnost hudebniho Ostravska. 1. vyd. Ostrava 2006, s. 23-44.

5 GREGOR. Vladimír. Hudební vlastivěda Olomouckého kraje. 1. vyd. Olomouc: Krajské nakladatelství, 1956.

6 GREGOR, Vladimír - ŠTĚDROŇ, Bohumír. Leoš Janáček, největši český skladatel z Moravy. 1. vyd. Praha, 1948.

7 Skladatel H. Vojáček a Janáčkovo rusofilství (Slezský sborník 60, 1962, s. 86-96), Janáčkovo přátelství s I. Wurmem (Slezský sborník 61, 1963, s. 103-111), Janáčkovy dopisy z pozi̊stalosti J. N. Poláška (Časopis Slezského muzea, série B 23, 1974, s. 72-78), Zdroje Janáčkova slovanství (Časopis Slezského muzea, série B 27, 1978, s. 72-92), Leoš Janáček a C. M. Hrazdira (Sborník praci Pedagogické fakulty v Ostravě, D-14, Praha 1978, s. 81-92), L. Janáček a Společnost pro výzkum dítěte v Brně (Opus musicum, 13, 1981, č. 9, s. 265-267).

8 Zejména monografie GREGOR, Vladimír - SEDLICKÝ, Tibor. Dějiny hudební výchovy $v$ českých zemích a na Slovensku. Praha: Státní pedagogické nakladatelství, ${ }^{1} 1973,{ }^{2} 1990$; GREGOR, V. Československá Společnost pro hudební výchovu (1934-1938) a mezinárodní dosah její činnosti. Praha: Státní pedagogické nakladatelství, 1974; GREGOR, V. František Bakule a jeho pěvecký sbor. 1. vyd. Praha: Státní pedagogické nakladatelství, 1982 a další.

GREGOR, Vladimír. Česká dètská píseň umělá. 1. vyd. Praha: Státní pedagogické nakladatelství, 1959.

10 GREGOR, Vladimír. Olomoucká a vídeňská léta skladatele A. Förchtgotta-Tovačovského. 1. vyd. Olomouc, 1959. 
teriálové studie publikované většinou v olomouckém Sborniku Střediska lidové umělecké kultury, ve Slezském sborníku či Hudebnich rozhledech. ${ }^{11}$

Velmi důležité místo v Gregorově hudebněhistorické orientaci na čas zaujaly pěvecké spolky. Silným podnětem byla př́íprava památníku olomouckého pěveckého spolku Žerotín v roce $1950,{ }^{12}$ který autor redigoval a do něhož přispěl i dvěma zásadními statěmi. Ještě v Olomouci však začaly Gregora zajímat i pěvecké spolky dělnické. Tato dosud zcela neprozkoumaná problematika vedla Gregora od dílčích studií, první již z roku $1954,{ }^{13}$ a pak už v Ostravě k syntetickému zpracování v knize Dělnické pěvecké spolky na Ostravsku a v jiných průmyslových střediscích českých zemi ${ }^{14}$ Právě Gregorův příchod do průmyslové Ostravy zintenzivnil jeho zájem o problematiku hornických dechových hudeb, ale i ostravského pěveckého spolku Marx ${ }^{15}$ a hlavně pak dvou skladatelů dlouhodobě či jen krátce působících na Ostravsku - Rudolfa Kubína ${ }^{16}$ a Ervína Schulhoffa. ${ }^{17}$

Vedle toho se však Gregorův zájem nadále v Ostravě ubíral směrem, který měl logické pokračování ve studiu regionálních hudebních dějin zvláště v severomoravských a slezských lokalitách v době 18.-20. století. Na tomto místě je nutné zmínit nejen poslední dvě Gregorovy knihy Obrozenská hudba na Moravě a ve Slezsku (1. vyd. Praha: Supraphon, 1983) a „posthumní“ Hudební mistopis Severomoravského kraje (1. vyd. Ostrava: Profil, 1987), ale i množství studií o hudební kultuře slezských zámků, klášterů a kolejí v 18. století hlavně ve Slezském sborniku, Časopisu Slezského muzea a hudební revui Opus musicum.

11 Byly to např́iklad stati: Dopisy Karla Bendla do Olomouce, $Z$ dopisů nár. umělce J. B. Foerstra olomouckému Žerotínu, Neznámá činnost P. Kř́ǐ̌kovského v Olomouci, Podíl Olomouce na české obrozenské hudbě, Vladimír Ambros - profil skladatele.Srovnej: ZENKL, Luděk - MALURA, Miroslav. Bibliografie prací doc. PhDr. Vladimíra Gregora, CSc. In Acta Facultatis Paedagogicae Universitatis Ostraviciensis, řada U-3. Ostrava: Pedagogická fakulta Ostravské univerzity v Ostravě, 1999, s. 87-98.

12 Památník pěvecko-hudebního spolku Žerotín v Olomouci (1880-1950) (ed. Vladimír GREGOR). Praha 1952.

13 GREGOR, Vladimír. Dělnické pěvecké spolky na Moravě. In Sborník Střediska lidové umělecké kultury. Olomouc: 1954, s. 83-96. GREGOR, Vladimír. Dělnické pěvecké spolky na Ostravsku. In Slezský sborník 55, 1957, s. 449-461. GREGOR, Vladimír. Organizace dělnických pěveckých spolků na Moravě a zvláště na Ostravsku. In Slezský sborník, 1959, roč. 57, s. 54-102.

14 GREGOR, Vladimír. Dělnické pěvecké spolky na Ostravsku a vjiných prümyslových střediscích českých zemí. 1. vyd. Ostrava: Krajské nakladatelství v Ostravě, 1961.

15 GREGOR, Vladimír. Z historie dělnického pěveckého spolku Marx v Ostravě-Vítkovicích. In Ostrava. Sborník k dějinám a výstavbě města 1. Ostrava: Krajské nakladatelství v Ostravě, 1963, s. 242-270.

16 GREGOR, Vladimír. Skladatel R. Kubín šedesátníkem. In Ostrava Sborník k dějinám a výstavbě města 5. Ostrava: Profil, 1969, s. 245-260; TÝŽ: Rudolf Kubín. Obraz života a díla. 1. vyd. Ostrava: Profil, 1975.

17 GREGOR, Vladimír. Skladatelská tvorba E. Schulhoffa v době jeho ostravského působení. In: Slezský sbornik. 1962, roč. 60, s. 397-403. 
Za téměř 40 let soustavné hudebněvědecké práce Gregor vytvořil poměrně rozsáhlé dílo čítající na 350 publikovaných odborných prací18 (z toho téměř celou třetinu tvoří větší muzikologické studie), půldruhé desítky knih, téměř jednu desítku vysokoškolských učebních textů a na dva a půl tisíce novinových kritik olomouckého a ostravského koncertního života, hudebněpublicistických a popularizačních článků. V Zenklově stati v Časopise Slezského muzea ke Gregorovým 60. narozeninám se píše: „Rozsáhlé a tematicky bohatě rozvětvené muzikologické dílo Vladimíra Gregora si již dávno žádá souhrnného zvážení, zvlášt když česká muzikologie formujici se v poslednich desetiletich $v$ soustavně budovaný pěstovaný obor usiluje o sebereflexi a o přehledné zpracování svých dosavadních výsledku [...]. " ${ }^{19}$ Luděk Zenkl publikoval ještě několik dalších statí věnovaných pracím Vladimíra Gregora, ${ }^{20}$ ale na objektivní, kritické zhodnocení Gregorova díla stále ještě čekáme. ${ }^{21}$

O sedm let mladším ostravským muzikologem než Vladimír Gregor byl již vzpomenutý Ivo Stolař́ík. Ten po válce začal pracovat v Československém rozhlase v Ostravě a v Praze jako hudební režisér a redaktor a přitom studoval (1947-1949) hudební vědu na Filozofické fakultě Univerzity Karlovy (díle jen UK) v Praze. Vysokoškolskou př́pravu však ukončil promocí na brněnské Filozofické fakultě MU v roce 1952 v oborech hudební věda a etnografie jako žák profesorů Jana Racka, Bohumíra Štědroně a Antonína Václavíka, kteří jej pak celoživotně ovlivnili. Po absolvování Filozofické fakulty v Brně - přr rádném studiu však stále pracoval v rozhlase až do konce roku 1953 - bylo Ivu Stolaříkovi nabídnuto prof. Janem Rackem místo odborného asistenta na brněnské katedře

18 Srv. ZENKL, Luděk - MALURA, Miroslav. Bibliografie prací doc. PhDr. Vladimíra Gregora, CSc. In Sborník praci Pedagogické fakulty Ostravské univerzity, řada U-3, 1999, s. 88-98. ZENKL, Luděk. Př́nos k rozvoji české socialistické muzikologie (K nedožitým šedesátinám Vladimíra Gregora). Časopis Slezského muzea, série B, 1976, roč. 25, s. 165.

19 Tamtéž.

20 Např́iklad ZENKL, Luděk. Vůdčí zjev slezské a severomoravské muzikologie (K nedožitým 70. narozeninám Vladimíra Gregora). Časopis Slezského muzea, série B, 1986, roč. 35, s. 73-79. ZENKL, Luděk. Počátky vědecké práce na ostravské katedře hudební výchovy (K nedožitým sedmdesátinám Vladimíra Gregora), TÝŽ. Heslo Vladimír Gregor v Biografickém slovníku severni Moravy a Slezska, sešit 6, Ostrava 1996, s. 38-40 nebo v pozn. č. 11 uvedená bibliografie Gregorových prací.

21 V nedávné době se však úkolu napsat knižní monografii o tomto hudebním historikovi a pedagogu ujala PhDr. Šárka Zedníčková, Ph.D. Ta dosud publikovala několik dílčích statí, jako např. Muzikolog a hudební pedagog Vladimír Gregor. In: Česká hudební pedagogika a vzdělávání dospělých na počátku 21. století. Praha: Divadelní ústav, 2006, s. 111-114; Muzikolog, hudební pedagog, a publicista Vladimír Gregor. In: Inovace v hudební pedagogice a výchově. K poctě Lea Kestenberga (1882-1962). Olomouc: Univerzita Palackého, Pedagogická fakulta, 2008, s. 114-115; Janáčkovská problematika v muzikologickém díle doc. Vladimíra Gregora. In: Janáček regionální a světový. Ostrava: Pedagogická fakulta OU, 2008, s. 103-106; Regionální hudební historie v muzikologickém odkazu Vladimíra Gregora. In: Mezinárodní webový sborník hudební výchovy 2008, č. 1, s. 305-308 nebo Vladimír Gregor: Rudolf Kubín. Obraz života a díla (portrét významné regionální umělecké osobnosti). In: Mezinárodní webový sborník hudební výchovy 2009, č. 2, s. 604-606. 
hudební vědy. Poněvadž se v té době Stolařík „na čistě vědeckou práci necitil ${ }^{\text {“22 }}$ (měl spíše silnou afinitu k praktickému muzikantství), tuto lákavou nabídku odmítl. Prof. Racek (tentokrát s velkým příznivcem rozhlasové práce, muzikologem a folkloristou dr. Karlem Vetterlem, a to na přání ředitele Slezského studijního ústavu v Opavě /dále jen SSÚ/ dr. Bohumila Sobotíka) po roce znovu zasáhl a tentokrát úspěšně přemluvil Iva Stolaříka, aby přijal uvolněné místo referenta pro hudební vědu ve SSÚ. A tak Stolaříkova činnost v tomto ústavu začala v lednu 1954. Vycházela ze dvou linií formulovaných zásadními statěmi, které byly otištěny ve Slezském sborníku, ${ }^{23}$ a samozřejmě také ze Stolaříkova zaměření na hudební historiografii a folkloristiku. Vědecké studie se slezskou a moravskou folklorní tematikou pak publikoval Stolařík ve Slezském sborníku a Radostné zemi i v zahraničních (zvl. polských a německých) sbornících. V oblasti etnologie a etnomuzikologie debutoval mladý vědec vydáním své disertace Hrčava. Monografie goralské obce ve Slezsku. ${ }^{24}$ Byla to pozoruhodná práce o komunikačně odlehlé goralské obci na pomezí česko-slovensko-polském, ideálním terénem pro zkoumání původního uchování tradiční kultury s minimálním množstvím civilizačních vlivů. Stolařík v ní shromáždil a popsal množství materiálu vypovídajícího o životě lidí v obci, o jejich hmotné kultuře, způsobu života plného specifických zvyků a obyčejů, o svérázných písních a tancích a podobně. Je tu např́íklad otištěno na 40 písní, které se předzpěvovaly k tanci ověnžok, a více jak desítka písní, spojených s jeho závěrečnou rychlou částí, zvanou kulanego. Notovými zápisy předzpěvů a nákresy figur je tu dokumentován tento typický dvoudobý párový točivý tanec; ve spojitosti s ním se na Hrčavě zachovalo také archetypické hudecké seskupení - hudec (skrzypek) a gajdoš (gajdek).

Tato velmi úspěšná pracovní etapa ve Stolaříkově životě skončila zrušením tří uměnovědných referátů opavského ústavu - literárního, kunsthistorického a muzikologického pražským Prezidiem Československé akademie věd. Ivo Stolařík byl pak jmenován ředitelem Státní filharmonie Ostrava a na vědeckou práci už mu nezbylo př́liš času (přesto na ni - jak dosvědčuje Stolaříkova bibliografie sestavená Miroslavem Malurou ${ }^{25}$ - úplně nezapomínal i na svých dalších „,nevědeckých“" pracovištích, byt' v omezeném rozsahu ${ }^{26}$ ).

22 STOLA ŘíK, Ivo. Život není fráze: Paměti a dokumentace. 1. vyd. Šenov u Ostravy: Tilia, 2002, s. 166.

23 RACEK, Jan. Problémy a úkoly slezské hudební historiografie. In Slezský sbornik. 1954, roč. 52 s. 1-23; VETTERL, Karel. Některé otázky hudební folkloristiky se zvláštním zřetelem k slezské oblasti. Tamtéž, s. 24-34.

24 STOLǍ̌íK, Ivo. Hrčava: Monografie goralské obce ve Slezsku. 1. vyd. Ostrava: Krajské nakladatelství, 1958.

25 MALURA, Miroslav. Soupis publikační činnosti - PhDr. Ivo Stolařík, CSc. In Acta Facultatis Paedagogicae Universitatis, řada U-3. Ostrava: Pedagogická fakulta Ostravské univerzity v Ostravě, 1999, s. 99-118.

26 Svědčí o tom nejen publikace vědeckých studií, ale zvláště získání kandidatury (CSc.) v době Stolaříkova dojíždění do pražského Supraphonu. 
Od 50. let 20. století napsal a zveřejnil řadu studií s hudebně historickou problematikou, zejména regionálně zaměřenou ve Slezském sborniku, ${ }^{27}$ ve sborníku Ostrava ${ }^{28}$ a ve Sborníku praci Pedagogické fakulty v Ostravě. ${ }^{29}$ Stolaříkovy časopisecké studie s janáčkovskou tematikou poskytly podklady pro další publikace,,$^{30}$ resp. edice korespondence. ${ }^{31}$ Jeho hudebně-historická badatelská práce umožnila novodobou premiéru Myslivečkovy opery Medont, král epirský v opavské opeře (1961).

Ivo Stolařík externě působil v 80 . a na počátku 90. let minulého století na katedře hudební výchovy Pedagogické fakulty v Ostravě (navázal tak na svou učitelskou činnost $\mathrm{v}$ oboru hudební folkloristiky na Filozofických fakultách MU v Brně a UK v Praze z 50. a 60. let). K hudebně historické práci se vrátil až $\mathrm{v}$ devadesátých letech, kdy připravoval k vydání své nejvýznamnějšś hudebněhistorické dílo o hudbě v prvorepublikové Ostravě, na kterém dlouhou dobu pracoval. V něm zpracoval rozsáhlý pramenný materiál, shromážděný při heuristickém vytěžení mnoha archivů (např. Archivu města Ostravy s fondy spolků, sdružení i institucí, Slezského zemského archivu v Opavě, kde je uložen fond Policejního ředitelství v Moravské Ostravě, Zemského archivu v Brně, Janáčkova archivu Moravského zemského muzea v Brně či literárního a hudebně historického archivu Národního muzea v Praze) a také získaný excerpcí dobového denního tisku.

Ke své etnografické a etnomuzikologické práci se mohl Ivo Stolařík soustavně vrátit až na konci své pracovní kariéry před důchodem, kdy byl zaměstnán ve Valašském muzeu $\mathrm{v}$ př́rodě $\mathrm{v}$ Rožnově pod Radhoštěm. Posledním velkým dílem I. Stolaříka byla jeho autorská spolupráce na prvních třech svazcích velké monografie o etnografickém regionu a lidové kultuře na Těšínsku, z přelomu tisíciletí (1997, 2000, 2001), na kterých pracoval společně s Jaroslavem Štikou a Věrou Tomolovou z rožnovského muzea. V nich byla použita obdobná metodologie (tentokrát aplikovaná na celý etnografický rajon) jako při zpracování jedné lokality obce Hrčava. Tímto unikátním pracovním a edičním počinem se završilo více jak půlstoletí trvající období vědecké a aktivní publikační činnosti, v němž Ivo Stolařík zveřejnil pět větších knižních publikací, dvanáct menších knížek

27 STOLAŘíK, Ivo - ŠTĚDROŇ, Bohumír. K dějinám hudby v Ostravském kraji. Slezský sborník, 1955, roč. 53, s. 195-229; STOLAŘÍK, I. Janáčkovy skladby v Ostravě v letech 1918-1938. Slezský sbornik, 1956, roč. 54, č. 4, s. 560-566; STOLAŘíK, I. Symfonická hudba v Ostravě v letech 1918-1938. Slezský sbornik, 1974, roč. 72, č. 2, s. 124-134.

STOLAŘÍK, Ivo. Kruh přátel vážné hudby v Moravské Ostravě. In Ostrava. Sborník k dějinám a výstavbě města 1. Ostrava: Krajské nakladatelství v Ostravě, 1963, s. 327-336; TÝŽ. Národní umělec Beno Blachut. In Ostrava. Sborník k dějinám a výstavbě města 14. Ostrava: Profil, 1987, s. 331-336.

29 STOLAŘ́́K, Ivo. Ostravská éra dirigenta Jana Šoupala. In Acta Facultatis Paedagogicae Universitatis, řada D-26. Praha: Státní pedagogické nakladatelství, 1989, s. 111-121.

30 Např. Leoš Janáček mezi svými. 1. vyd. Šenov u Ostravy: Tilia, 1999; TÝŽ. Leoš Janáček ústy pamětníků. 1. vyd. Šenov u Ostravy: Tilia, 2003.

31 STOLAŘÍK, Ivo. Jan Löwenbach a Leoš Janáček: Vzájemná korespondence. 1. vyd. Opava: SSÚ, 1958. 
a edic korespondence, na padesát sborníkových a časopiseckých studií a statí, sedm desítek hesel hudebníků z Ostravska a českého Slezska v Československém hudebnim slovniku, kolem osmi set novinových článků, nekrologů, recenzí, kritik, zpráv o výzkumu, rozhovorů, rozborů skladeb do koncertních programů apod. Na tomto místě je vhodné znovu prripomenout, že Ivo Stolařík byl ve své pracovní kariéře zaměstnán jen ve dvou vědeckovýzkumných institucích, kde se mohl soustavně věnovat vědecké práci, a to relativně krátkou dobu. Ta u něj proto často musela být jen vedlejší, zájmovou činností. V ní se Stolařík zaměřil zvláště na dva př́ibuzné obory: hudební historiografii svého regionu (na samém počátku stála - jak již bylo uvedeno - rozsáhlá studie z roku 1955 ve Slezském sborníku, napsaná $\mathrm{v}$ autorské spolupráci s prof. Bohumírem Štědroněm, K dějinám hudby v Ostravském kraji a završuje ji kniha Umělecká hudba v Ostravě 1918-1938, vydaná roku 1997) a etnologii (v tomto oboru stojí na prvním místě knižně vydaná disertace Hrčava (1958) a uzavírá je monografie Těšinsko. ${ }^{32}$

Vedle těchto dvou muzikologů působili v Ostravě a v blízké Opavě také další absolventi brněnské muzikologické školy Miloslav Navrátil (1932), Miroslav Malura (1937-2000), Miroslav Kaduch (1938-2005) či autor tohoto příspěvku (nepočítáme-li významného violoncellistu a ostravského „kronikářr“ zdejšího hudebního života Ivana Měrku) a pak i někteř́ další ostravští hudební teoretici a historici, kteří získali muzikologické školení jinde (např. v Olomouci u dalšího Helfertova žáka Roberta Smetany), jako Karel Boženek (1938), Ondřej Bednarčík (1929-1998) či Jan Mazurek (1941). Ten se badatelsky věnoval hlavně dějinám české hudební výchovy, problémům školské hudební recepce a zvláště problematice dějin regionální hudební kultury na Ostravsku. V této své činnosti šel Mazurek zcela ve stopách svého předchůdce doc. Vladimíra Gregora; Mazurek sice nebyl př́mým Gregorovým žákem, ale právě přičiněním tohoto tehdejšího vedoucího katedry hudební výchovy se stal Mazurek v roce 1973 odborným asistentem na Pedagogické fakultě v Ostravě. O dva roky později zde získal po rigorózním rrízení titul $\mathrm{PhDr} .^{33} \mathrm{a} \mathrm{v}$ dalších letech pokračoval ve svém odborném růstu. ${ }^{34}$ Stejně jako směr muzikologické činnosti Vladimíra Gregora nejvíce ovlivnil Bohumír Štědroň, tak lze bez nadsázky přirovnat Gregorův vliv na pracovní

32 Těšinsko I-V (eds. Ivo STOLAŘíK - Jaroslav ŠTIKA - Věra TOMOLOVÁ). Vydalo Vlastivědné muzeum v Českém Těšíně v nakladatelství Tilia, 1997, 2000, 2001, 2002 a 2003.

Pro rigorózum J. Mazurek př́dložil v roce 1975 disertaci Expresionismus a česká hudba 20. století (do konce 30. let); doc. dr. Vladimír Gregor, CSc. byl jednak ve funkci školitele, jednak předsedou rigorózní komise, v níž zasedli jako členové prof. Josef Schreiber, dr. Jiř́ Svoboda, CSc. a doc. Karel Tvarůžka. Vladimír Gregor hodlal po patnácti letech vedení katedry, kterou v roce 1959 vybudoval, předat některému z mladších kolegů a Jana Mazurka si vytipoval jako svého eventuálního nástupce. V roce 1974 se však po Gregorově abdikaci stal vedoucím katedry hudební výchovy o dvanáct let starší Ondřej Bednarčík, CSc., který byl jmenován v roce 1985 docentem, a Jan Mazurek zastával funkci tajemníka katedry.

34 V roce 1982 pak získal na UK v Praze titul kandidáta pedagogických věd za práci Podíl soudobé hudby na rozvoji osobnosti žáka 2. stupně základní školy (Praha 1982). Docentem Teorie vyučování hudební výchově byl jmenován v roce 1988 a v roce 1994 se habilitoval jako docent Hudební výchovy se zaměřením na dějiny hudby na základě habilitačního spisu 
orientaci Jana Mazurka. Také on se po príchodu na ostravskou Pedagogickou fakultu zaměřil - jako Gregor - na podobnou regionální problematiku Ostravska a na dějiny české (a v mnoha př́padech prímo regionální - tj. ostravské) hudební výchovy. ${ }^{35} \mathrm{~A}$ tak uzavíráme tento př́spěvek konstatováním: ačkoliv nemůžeme mluvit v Ostravě o žádné skupině hudebních vědců (tř̌eba organizované v dřrívějším Svazu československých skladatelů), kteří by ve svém zaměření vykazovali jednotný metodologicky či programově orientovaný směr a o nichž by se dalo s určitou nadsázkou hovořit jako o př́ílušnících „ostravské muzikologické školy“, přece jen si dovolujeme vyslovit hypotézu, že kdyby v tomto městě na pomezí severovýchodní Moravy a českého Slezska působilo od 50. let minulého století více odborně vyškolených muzikologů např́klad v Praze či v Bratislavě, nebylo by zde dosaženo na muzikologickém poli takových výsledků jako se dosáhlo dodnes. A to díky Helfertovým žákům, profesorům a doktorům věd Janu Rackovi, Bohumíru Štědroňovi, Robertu Smetanovi či Jiř́mu Vysloužilovi, který sice nebyl Helfertovým žákem, ale můžeme ho označit za jeho př́ímého pokračovatele.

Karel Steinmetz (karel.steinmetz@osu.cz), Katedra hudební výchovy, Pedagogická fakulta, Ostravská univerzita v Ostravě.

\section{ABSTRACT \\ INFLUENCE OF HELFERTS' PUPILS ON POSTWAR OSTRAVA MUSICOLOGY}

Although there was not a musicological institution such as an university or academic institute in the region of Ostrava (with the exception of short duration of musicological department at the Silesian Institute of the Academy of Sciences in Opava), trained musicologists from Brno of Olomouc were active in the local cultural and educational establishments, such as Vladimír Gregor (19161986), Ivo Stolař́k (1923-2010), Miloslav Navrátil (1932), Miroslav Malura (1937-2000), Karel Boženek (1938), Miroslav Kaduch (1938-2005), Jan Mazurek (1941) and others. The author examines how their musicologic work was influenced by lecturers from generation of Helferts'scholars - Jan Racek, Bohumír Štědroň, Robert Smetana and Jiří Vysloužil.

\section{Key words}

scholars of Vladimír Helfert, Musicology in Ostrava, Ivo Stolařík, Vladimír Gregor

Kapitoly z dějin ostravské hudebni výchovy v obdobi 1890-1945 (Ostrava 1994), profesorem v oboru Hudební teorie a pedagogika se stal v roce 2001.

Je sice pravda, že Gregorovo muzikologické dílo je rozsáhlejší, ale okruh badatelského zájmu obou osobností je velmi podobný (snad s výjimkou hudební historie olomouckého regionu a širší problematiky moravské, kterým se věnoval jen Vladimír Gregor). 


\section{Bibliography}

GREGOR, Vladimír. Rudolf Kubin. Obraz života a díla. 1. vyd. Ostrava: Profil, 1975.

MALURA, M. Soupis publikační činnosti - PhDr. Ivo Stolařík, CSc. In Acta Facultatis Paedagogicae Universitatis, řada U-3. Ostrava: Pedagogická fakulta Ostravské univerzity v Ostravě, 1999, s. 99-118.

MAZUREK, Jan - STEINMETZ, Karel et al. Ostravská hudebni kultura od konce 19. století do současnosti. 1. vyd. Ostrava: Ostravská univerzita - Pedagogická fakulta, 2010.

RACEK, Jan. Problémy a úkoly slezské hudební historiografie. In Slezský sbornik, 1954, roč. 52, s. $1-23$.

STEINMETZ, Karel - BOŽENEK, Karel - MAZUREK, Jan. Ivo Stolařik: Osobnost hudebního Ostravska. 1. vyd. Ostrava: Montanex, 2006.

STOLAŘíK, Ivo. Hrčava: Monografie goralské obce ve Slezsku. 1. vyd. Ostrava: Krajské nakladatelství v Ostravě, 1958.

STOLAŘÍK, Ivo. Umělecká hudba v Ostravě (1918-1938). 1. vyd. Šenov u Ostravy: Tilia, 1997.

STOLAŘÍK, Ivo. Život není fráze: Paměti a dokumentace. 1. vyd. Šenov u Ostravy: Tilia, 2002, s. 166.

VETTERL, Karel. Některé otázky hudební folkloristiky se zvláštním zřetelem k slezské oblasti. In Slezský sbornik, 1954, roč. 52, s. 24-34.

ZENKL, Luděk - MALURA, Miroslav. Bibliografie prací doc. PhDr. Vladimíra Gregora, CSc. In Acta Facultatis Paedagogicae Universitatis Ostraviciensis, řada U-3. Ostrava: Pedagogická fakulta Ostravské univerzity v Ostravě, 1999, s. 87-98.

ZENKL, Luděk. Př́nos k rozvoji české socialistické muzikologie (K nedožitým šedesátinám Vladimíra Gregora). Časopis Slezského muzea, série B, 1976, roč. 25, s. 165.

ZENKL, Luděk. Vůdčí zjev slezské a severomoravské muzikologie (K nedožitým 70. narozeninám Vladimíra Gregora). Časopis Slezského muzea, série B, roč. 35, 1986, s. 73-79. 
